\title{
Membina Karakter Anak Melalui Program Full Day School Berbasis Nilai-Nilai Kepesantrenan \\ (Studi Kasus di Madrasah Ibtidaiyah Nurul Ummah Kotagede Yogyakarta)
}

\author{
Zainun Wafiqatun Niam \\ Universitas Islam Negeri Sunan Kalijaga Yogyakarta \\ masniam780@gmail.com
}

\begin{abstract}
Character building is an important step in the process of education, especially Islamic education. The occurrence of various forms of immoral behavior from the community, especially students is an increasingly problematic education today. Character building needs to be done early on to students, both within the family and educational institutions. This paper is intended to look at the process of character building in one of the Madrasah Ibtidaiyah institutions in Yogyakarta that applies the Fullday school model with a boarding school education base. The formulation of the problem to be answered is about how the process of implementing the Fullday school system in fostering children's character and how to foster children's character with boarding-based values. The results of the study show that character building through the Fullday school program can run more effectively because the teacher's guidance to students is more intensive. In addition, the planting of the values of the pesantren can provide students with supplies, such as serving the parents, living a simple and thrifty life, discipline, and so on. Character education and coaching in MI Nurul Ummah is the parents' choice because education obtained by children outside the home can be guaranteed.
\end{abstract}

Keywords: Character, Full day School, Islamic values

\begin{abstract}
Abstrak: Pembinaan karakter merupakan langkah penting di dalam proses pendidikan, khususnya pendidikan Islam. Terjadinya berbagai bentuk perilaku tidak bermoral dari masyarakat, khususnya peserta didik merupakan permasalahan pendidikan yang kian meningkat dewasa ini. Pembinaan karakter perlu dilakukan sejak dini kepada peserta didik, baik di dalam keluarga maupun lembaga pendidikan. Tulisan ini ditujukan
\end{abstract}


untuk melihat proses pembinaan karakter di salah satu lembaga Madrasah Ibtidaiyah di Yogyakarta yang menerapkan model full day school dengan basis pendidikan pesantren. Rumusan masalah yang ingin dijawab adalah tentang bagaimana proses penerapan sistem full day school dalam membina karakter anak dan bagaimana pembinaan karakter anak dengan nilai-nilai berbasis pesantren. Hasil dari kajian menunjukkan bahwa pembinaan karakter melalui program full day school dapat berjalan lebih efektif karena pembinaan guru terhadap peserta didik lebih intensif. Selain itu, penanaman nilai-nilai kepesantrenan dapat memberi bekal kepada peserta didik, seperti berbakti kepada orang tua, hidup sederhana dan hemat, disiplin, dan sebagainya. Pendidikan dan pembinaan karakter di MI Nurul Ummah menjadi pilihan orang tua murid dikarenakan pendidikan yang didapatkan anak di luar rumah dapat terjamin.

Kata Kunci: Karakter, Full day School, Nilai-Nilai Kepesantrenan

\section{Pendahuluan}

Pendidikan ditujukan untuk membentuk manusia yang berkarakter dan berwawasan luas. Namun, globalisasi dan modernisasi telah mempengaruhi pandangan manusia tentang makna pendidikan. Pandangan tentang pendidikan sebagai pembentukan karakter menjadi hal yang bukan prioritas lagi, melainkan pendidikan untuk menciptakan pekerja terampil yang dapat bekerja mengisi industri dan perusahaan-perusahaan bonafit menjadi lebih prioritas. Sehingga yang terjadi adalah banyaknya manusia terampil dan cerdas namun minim akan karakter atau moral yang baik.

Pendidikan untuk membentuk karakter yang baik dapat dilakukan sejak usia dini, karena usia dini merupakan keadaan di mana perkembangan manusia ideal untuk dibentuk watak dan karakternya. Pembentukan dan pembinaan karakter manusia sejak dini harus dilakukan dengan pola asuhan yang baik dan total. Lembaga pendidikan sebagai salah satu tempat pembentukan kepribadian manusia memiliki tanggung jawab besar terhadap pembinaan karakter anak. Terlebih lembaga pendidikan Islam yang memiliki ciri khas penanaman nilai-nilai luhur yang bersumber pada Alquran dan Sunnah. Lembaga pendidikan Islam, terutama pesantren memiliki peran strategis dalam pembentukan dan pembinaan karakter anak, karena waktu yang diberikan dalam pengasuhan siswa lebih banyak, dan nilai-nilai yang diajarkan dalam pesantren merupakan nilai-nilai karakter yang luhur. 
Model pendidikan seperti pesantren dapat diterapkan di dalam lembaga pendidikan formal seperti madrasah atau sekolah. Madrasah atau sekolah dapat menerapkan sistem belajar full dalam sehari atau full day school untuk memberikan pola asuh terhadap peserta didik secara intensif, khususnya dalam pembinaan karakter. Program full day school tersebut jika diterapkan pada sekolah atau madrasah tingkat dasar maka diharapkan dapat memberikan hasil atau output yang baik bagi peserta didik di tingkat dasar.

Tulisan ini ditujukan untuk melihat bagaimana proses pendidikan dan pembinaan karakter anak didik di tingkat dasar, yaitu di Madrasah Ibtidaiyah Nurul Ummah Kotagede Yoguakarta. Hal ini dirasa menarik karena lembaga ini telah menerapkan program full day school dengan program tahsin dan tahfidz unggulannya. Selain itu, karena berada di bawah naungan Pesantren MI Nurul Ummah memiliki karakter tersendiri dalam proses pembinaan karakter peserta didik, yaitu dengan penanaman nilai-nilai yang ada dalam pesantren.

\section{Pendidikan Karakter}

Salah satu tujuan pendidikan berdasarkan taksonomi Bloom adalah tujuan afektif, yaitu pendidikan sebagai upaya untuk mengembangkan sikap, perasaan, nilai-nilai luhur, emosional dan moral. ${ }^{1}$ Meskipun kedua tujuan lainnya yaitu kognitif dan psiko-motor merupakan tujuan yang sama pentingnya, akan tetapi tujuan afektif memiliki peran urgen di dalam konsep pendidikan masa sekarang. Tujuan afektif inilah yang menurut perkembangannya lebih dikenal dengan paradigma bahwa pendidikan adalah untuk membentuk kepribadian atau karakter manusia.

Berdasarkan penelitian sejarah dari seluruh negara yang ada di dunia, pada dasarnya pendidikan memiliki dua tujuan, yaitu membimbing para generasi muda untk menjadi cerdas dan memiliki perilaku baik. Kata "cerdas" dan "baik" bukanlah dua kata yang sama. Menyadari hal tersebut, para pemangku kebijakan sejak zaman Plato telah membuat suatu kebijakan mengenai pendidikan moral yang secara sengaja dibuat sebagai bagian utama dari pendidikan sekolah. Mereka telah mendidik karakter masyarakat setara dengan pendidikan inteligensi, mendidik kesopanan setara pendidikan literasi, mendidik kebajikan setara dengan pendidikan ilmu pengetahuan. ${ }^{2}$

\footnotetext{
${ }^{1}$ S. Nasution, Teknologi pendidikan, (Jakarta: Bumi Aksara, 1994), hal. 24-25.

2 Thomas Lickona, Educating For Character: Bagaimana Sekolab Dapat Mengajarkan Sikap Hormat dan Tanggung Jawab, (Jakarta: PT Bumi Aksara, 2012), hal.7-8
} 
Pentingnya pendidikan sebagai upaya pengembangan karakter manusia dapat dilihat dari situasi sosial, kultural masyarakat saat akhir-akhir ini memang semakin mengkhawatirkan. Ada berbagai macam peristiwa dalam pendidikan yang semakin merendahkan harkat dan martabat manusia. Hancurnya nilai-nilai moral, merebaknya ketidakadilan, tipisnya rasa solidaritas, dan lain sebagainya telah terjadi dalam lembaga pendidikan kita. Pengembangan karakter menjadi semakin mendesak untuk diterapkan dalam lembaga pendidikan kita mengingat berbagai macam perilaku yang non-edukatif kini telah menyerambah dalam lembaga pendidikan kita, seperti fenomena kekerasan, pelecehan seksual dan sebagainya. ${ }^{3}$ Menghadirkan pendidikan yang berorientasi pada pengembangan dan perbaikan karakter merupakan upaya untuk mereduksi fenomena-fenomena non-edukatif di atas. Selain itu pendidikan yang menekankan pada pengembangan karakter juga merupakan sebuah upaya dalam mengembalikan makna pendidikan yang sesungguhnya, yaitu menciptakan manusia yang memiliki etika baik dan cerdas dalam berkehidupan.

Orang berkarakter adalah orang yang berkepribadian, berperilaku, bersifat, bertabiat, atau berwatak. Karakter mulia (good character) mencakup pengetahuan tentang kebaikan (moral knowing) yang menimbulkan komitmen terhadap kebaikan (moral feeling), dan akhirnya benar-benar melakukan kebaikan (moral behavior). Dengan demikian, karakter mengacu pada serangkaian pengetahuan (cognitive), sikap (attitudes) dan motivasi (motivations), serta perilaku (behaviors) dan keterampilan. Menurut Foerster ada empat ciri dasar karakter, yaitu:

1. Keteraturan interiorn di mana setiap tindakan diukur berdasarkan hierarki nilai. Nilai menjadi pedoman normatif setiap tindakan.

2. Koherensi yang memberi keberanian, membuat seseorang teguh pada prinsip, tidak mudah terombang-ambing pada situasi baru atau takut resiko. Koherensi merupakan dasar yang membangun rasa percaya satu sama lain. Tidak adanya koherensi meruntuhkan kredibilitas seseorang.

3. Otonomi. Di situ seseorang menginternalisasikan aturan dari luar sampai menjadi nilai-nilai pribadi tanpa pengaruh atau desakan pihak lain.

${ }^{3}$ Doni Koesoema, Pendidikan karakter, (Jakarta: Grasindo, 2010), hal.112-113. 
4. Keteguhan dan kesetiaan. Keteguhan merupakan daya tahan seseorang guna mengingini apa yang dipandang baik. Dan kesetiaan merupakan dasar bagi penghormatan atas komitmen yang dipilih. ${ }^{4}$

Di dalam pendidikan Islam, karakter lebih dikenal sebagai pendidikan akhlak yang merupakan inti dari pendidikan Islam. Akhlak atau karakter terwujud dalam ekspresi manusia, baik dari cara berbicara, bertindak, bahkan berpikir. Akhlak yang termanifestasikan ke dalam tindakan tersebut melekat dalam diri seseorang yang menjadi identitas dan karakter sehingga sulit bagi seseorang untuk memanipulasinya. Menurut Al-Ghazali, akhlak adalah sifat atau bentuk keadaan yang tertanam dalam jiwa, yang dari padanya lahir perbuatanperbuatan dengan mudah dan gampang tanpa perlu dipikirkan dan dipertimbangkan lagi. Di dalam Islam, pentingnya pendidikan karakter dapat dilihat dari penekanan pendidikan akhlak yang secara teoritis berpedoman kepada Al-Quran dan secara praktis mengacu kepada kepribadian Nabi Muhammad Saw. Keteladanannya tak diragukan lagi dan telah disebutkan dalam Al Quran, "Dan sesungguhnya kamu benar-benar berbudi pekerti agung (Q.S Al-Qalam [68]:4). Dan dalam hadis Nabi Muahammad Saw bersabda, "Sesungguhnya aku diutus ke muka bumi ini adalah untuk menyempurnakan akhlak manusia".5

Pada hakikatnya pendidikan Islam adalah untuk membentuk anak didik menjadi manusia yang berkarakter atau bernilai, memiliki akhlak yang mulia sehingga menjadi manusia yang diridhai Allah Swt. Pendidikan karakter merumuskan nilai-nilai yang harus dimiliki oleh anak didik setelah selesai mengikuti proses pembelajaran di dalam ataupun di luar kelas. Pada hakikatnya dalam pendidikan Islam pun nilai-nilai tersebut menjadi tujuan utama setelah kegiatan pembelajaran maupun kegiatan lain di sekolah. Oleh karena itu, apa yang menjadi dasar pendidikan Islam merupakan dasar pijakan dalam penetapan konsep pendidikan karakter juga. Hal tersebut dapat dilihat dari nilai-nilai atau karakter yang dirumuskan tidak bertentangan dengan dasar atau sumber pendidikan Islam yaitu Al-Quran, Al-Sunnah, dan Ijtihad. Karakter-karakter dasar yang dirumuskan baik oleh Indonesian Heritage Foundation antara lain: cinta kepada Allah dan semesta beserta isinya, tanggung jawab disiplin dan mandiri, jujur, hormat dan santun, kasih sayang, peduli, dan kerjasama, percaya

\footnotetext{
${ }^{4}$ Fifi Nofiaturrahmah, Metode Pendidikan Karakter di Pesantren, Jurnal Pendidikan Agama Islam, Vol.XI, No.2, (Desember, 2014).

5Johansyah, Pendidikan Karakter dalam Islam; Kajian dari Aspek Metodologis, Jurnal Ilmiah Islam Futura, Vol.11, No.1, (Agustus, 2011).
} 
diri, kreatif, kerja keras, dan pantang menyerah, keadilan dan kepemimpinan, baik dan rendah hati, toleransi, cinta damai, dan persatuan. ${ }^{6}$

Melalui tulisan ini, penulis mencoba melihat proses pendidikan dan pembinaan karakter di dalam lingkungan Madrasah Ibtidaiyah Nurul Ummah Kotagede. Madrasah Ibtidiaiyah Nurul Ummah merupakan salah satu madrasah yang berada di kota Yogyakarta. Pendirian madrasah ini merupakan sebuah usaha untuk mengisi kekurangan madrasah di tingkat sekolah dasar di kota Yogyakarta, yang pada saat penrdiriannya hanya terdapat dua madrasah ibtidaiyah. MI Nurul Ummah merupakan lembaga yang berada di bawah yayasan pendidikan Bina Putra di kotagede. Sejak awal berdiri Yayasan Pendidikan Bina Putera memiliki beberapa lembaga madrasah, seperti madrasah Tsanawiyah, Madrasah Aliyah dan Madrasah Diniyah Nurul Ummah. Pada tahun 2015 Yayasan Pendidikan Bina Putera mulai mendirikan Madrasah Ibtidaiyah Nurul Ummah.

Pendirian MI Nurul Ummah tidak sebatas hanya untuk melengkapi tingkatan jenjang pendidikan yang sudah ada di Yayasan Bina Putera, melainkan sebuah usaha baru untuk mewujudkan lembaga sekolah dasar Islam yang memiliki karakter tersendiri. MI Nurul Ummah menawarkan sistem pendidikan Islam yang mencoba membekali anak didik dengan pengetahuan umum dan agama secara bersama-sama. Selain itu, program fullday school ditawarkan oleh MI Nurul Ummah kepada masyarakat yang menginginkan putera-puterinya mendapat pendidikan yang lebih intensif di sekolah. Sebagian masyarakat yang bekerja di luar rumah hingga sore hari merasa tertarik dengan program fullday school MI Nurul Ummah.

MI Nurul Ummah menyelenggarakan konsep pendidikan Islam yang berlandaskan pendidikan pesantren. Program unggulan dari program MI Nurul Ummah adalah tahsin dan tahfidz Al quran, selain itu tradisi-tradisi luhur dari pesantren dikenalkan kepada peserta didik. Seluruh program yang dijalankan merupakan usaha penanaman karakter kepada peserta didik yang berlandaskan nilai-nilai kepesantrenan. Lebih jauh lagi, melalui program fullday school dapat menunjang proses penanaman karakter tersebut, karena melalui pendampingan secara penuh selama peserta didik di madrasah proses pembinaan dan penanaman karakter islami dapat diwujudkan dengan baik.

${ }^{6}$ Hilda Ainissyifa, Pendidikan Karakter dalam Perspektif Pendidikan Islam, Jurnal Pendidikan Universitas Garut, ISSN: 1907-932X, Vol.8, No.01, 2014;1-26. 


\section{Pembinaan Karakter Anak}

Masa usia prasekolah merupakan saat yang paling penting dalam rentang kehidupan. Hal ini karena pada usia ini perkembangan kecerdasan anak mengalami peningkatan yang pesat, dan anak mulai sensitif menerima berbagai upaya untuk mengembangkan seluruh potensi yang ada pada dirinya. Selain itu pada masa prasekolah mulai ditanamkan landasan pembentukan tingkah laku melalui pembiasaan dan latihan. Pembentukan tingkah laku anak berjalan seiring dengan proses penyesuaian diri anak dengan lingkungan sosialnya yang mulai beragam. Anak yang awalnya hanya memperhatikan kebutuhan dan keinginan sendiri dengan ketergantungan kuat pada keluarga, secara berproses beralih ke tingkat kemandirian lebih tinggi. Hal ini ditunjukkan dengan terbentuknya kemampuan untuk menyesuaikan diri dengan lingkungan sosialnya. Dengan berkembangnya lingkungan sosial, maka berkembang juga minat-minat pribadi yang antara satu anak dengan anak lain berbeda. Sejalan dengan ciri khas periode ini sebagai masa bermain, hampir seluruh kegiatan pada usia prasekolah melibatkan unsur bermain. ${ }^{7}$

Menurut Piaget, perkembangan moral anak meliputi tiga tahap, yaitu, 1) pre-moral, 2) moral realism, dan 3) moral realitivism. Penjelasan dari tahapan tersebut intinya adalah bahwa tahap awal anak belum mengenal aturan, moral, etika, dan susila. Kemudian berkembang menjadi individu yang mengenal aturan, moral, dan etika yang kemudian bertindak mengikuti aturan tersebut. Pada akhirnya, nilai, moral dan aturan melekat pada diri anak yang kemudian menjadi pengendali yang membuat anak berperilaku berdasarkan pertimbangan moral yang ada pada dirinya, bukan atas dasar aturan yang ada atau keberadaan orang lain. ${ }^{8}$ Anak usia SD berada pada tahap moral realism, di mana mereka berada pada perkembangan mengenal dan cenderung mengikuti nilai atau moral tersebut. Sehingga, anak usia SD memerlukan pembinaan dan pendidikan karakter untuk membentuk pribadi yang memiliki moral baik.

Berdasarkan perkembangan di atas maka proses belajar perlu disesuaikan dengan tingkat perkembangan siswa. Untuk mendukung hal tersebut, diperlukan hal tersebut, diperlukan pemahaman para guru mengenai karakteristik siswa dan proses pembelajarannya, khususnya ditingkat SD. Selain itu, hal tersebut ditandai dengan kondisi yang sangat memengaruhi penyesuaian pribadi dan sosial anak.

\footnotetext{
${ }^{7}$ Lembaga Penelitian Universitas Negeri Yogyakarta, Tinjauan Berbagai Aspek. Character Building: Bagaimana Mendidik Anak Berkarakter, (Yogyakarta: Tiara Wacana, 2008), Hal. 13-14.

${ }^{8}$ Slamet Suyanto, Pendidikan Karakter untuk. Anak Usia Dini, Jurnal Pendidikan Anak, Vol.1, Edisi 1 Juni 2011.
} 
Berkaitan dengan hal tersebut, ada beberapa tugas perkembangan siswa di sekolah dasar, di antaranya; mengembangkan konsep-konsep yang perlu bagi kehidupan sehari-hari; mengembangkan kata hari, moralitas, dan nilai-nilai; mencapai kebebasan pribadi; dan mengembangkan sikap-sikap terhadap kelompok-kelompok dan institusi-institusi sosial. ${ }^{9}$

Pendampingan dan pembinaan karakter terhadap anak didik dianggap hal yang sangat penting bagi siswa-siswi MI Nurul Ummah. Karena usia mereka adalah usia yang sesuai dengan perkembangan pribadi anak untuk membentuk perilaku yang baik.Pembinaan karakter di usia mereka menjadi tolak ukur dan pondasi bagi karakter mereka di masa depan.

Berdasarkan dari apa yang dikatakan oleh kepala Madrasah Ibtidaiyah Nurul Ummah, bahwa output dari pembinaan karakter peserta didik tidak semata-mata untuk tujuan pembentukan karakter peserta didik selama mereka bersekolah di MI Nurul Ummah. Akan tetapi output yang diusahakan adalah terbentuknya karakter peserta didik setelah mereka lulus dari MI Nurul Ummah. Selama 6 tahun peserta didik mendapat bimbingan dan pembinaan karakter diharapkan mampu menjadi pondasi kuat terhadap pembentukan watak mereka di usia dewasa. Usaha pembentukan perilaku positif sejak dini tersebut juga dilakukan dengan menargetkan peserta didik untuk mengahfal minimal lima hingga sepuluh juz Al quran ketika mereka lulus dari MI Nurul Ummah.

\section{Pembinaan Karakter dengan Full Day School}

Full day school merupakan satu istilah dari proses pembelajaran yang dilaksanakan secara penuh, aktifitas anak lebih banyak dilakukan di sekolah dari pada di rumah. Proses pembelajaran yang lebih lama di sekolah tidak hanya berlangsung di dalam kelas, karena konsep awal dibentuknya sistem full day school bukan menambah materi ajar dan jam pelajaran yang sudah diterapkan oleh pemerintah, melainkan tambahan jam sekolah digunakan untuk pengayaan materi ajar yang disampaikan dengan metode pembelajaran yang kreatif dan menyenangkan untuk menambah wawasan dan memperdalam ilmu pengetahuan, menyelesaikan tugas dengan bimbingan guru, pembinaan mental,

\footnotetext{
${ }^{9}$ Novan Ardi Wiyani, Konsep Praktik, \& Strategi Membumikan Pendidikan Karakter di SD, (Yogyakarta: Ar-Ruzz Media, 2013), hal.145-146
} 
jiwa, dan karakter anak. Dengan kata lain konsep dasar dari full day school adalah integrated curriculum dan integrated activity. ${ }^{10}$

Peraturan pemerintah Indonesia melalui Menteri Pendidikan dan Kebudayaan Republik Indonesia mengatakan bahwa program full day school memiliki beberapa alasan, yaitu: ${ }^{11}$

1. Tidak terdapat mata pelajaran

Program full day school diterapkan oleh pemerintah dengan tidak memberi jam tambahan pelajaran. Tetapi dalam jam tambahan tersebut tidak ada mata pelajaran yang membuat siswa bosan. Kegiatan yang dilakukan adalah ekstrakuliluler. Kegiatan ekstrakulikuler tersebut akan merangkum hingga 18 karakter, seperti jujur, toleransi, disiplin, hingga cinta tanah air. Melalui kegiatan tersebut dia mengatakan bahwa siswa dapat dijauhkan dari perbuatan negatif.

2. Orang tua dapat menjemput anak ke sekolah

Alasan lain dari full day school adalah masalah hubungan orang tua dengan anak. Khususnya untuk masyarakat yang tinggal di daerah perkotaan, pada umumnya orang tua bekerja hingga pukul 5 sore. Dengan program full day school, orang tua dapat menjemput anak ketika pulang kerja.

3. Membantu memberikan sertifikasi ke guru

Full day school diharapkan dapat memberi kesempatan kepada guru untuk mendapatkan durasi jam mengajar 24 jam perminggu sebagai syarat mendapatkan sertifikasi.

Sistem fullday school MI Nurul Ummah ditekankan kepada proses pembelajaran tahsin dan tahfidz Alquran. Pembelajaran tahsin dan tahfidz dapat membekali moral baik peserta didik, karena pendidikan dan pembelajaran berbasis Alquran adalah pendidikan yang mengupas masalah Alquran dalam makna; membaca (tilawah), memahami (tadabbur), menghafal (tahfid ) dan mengamalkan serta mengajarkan atau memliharanya melalui berbagai unsur. Pendidikan Alquran adalah pendidikan yang menerapkan nilai-nilai yang terkandung dalam Alquran yang terlihat dalam sikap dan aktifitas peserta didik di

${ }^{10}$ Ida Nurhayati Setiyarini, dkk, Penerapan Sistem Pembelajaran "Fun and Fullday School" Untuk Meningkatkann Religiusitas Peserta Didik di SD IT Al Islam Kudus, Jurnal Teknologi Pendidikan dan Pembelajaran, Vol.2, No.2, hal.231-244 (April 2014). ISSN: 2354-6441.

${ }^{11}$ https://nasional.tempo.co/read/794640/3-alasan-menteri-muhadjir-full-day-schoolakan-menyenangkan, diakses pada hari Jumat, 19 Oktober 2018 pukul 21.00. 
mana pun dia berada. ${ }^{12}$ Dengan sistem full day school tersebut pembelajaran tabsin dan tabfidz dianggap lebih maksimal, karena alokasi waktu yang diberikan lebih banyak. Sehingga kemampuan anak untuk menghafal Al quran lebih banyak.

Melalui program full day school pembinaan karakter perserta didik di MI Nurul Ummah dilakukan tidak hanya di dalam kelas, melainkan lebih banyak dilakukan di luar kelas. Hal itu menjadi kesepakatan bersama para pendidik untuk membiasakan karakter baik pada anak di setiap aktivitas, misalnya siswa dibiasakan bersalaman dengan para guru ketika mereka datang. Selain itu, pembiasaan karakter disiplin juga diberikan kepada peserta didik, dimulai dari siswa diminta untuk membaca asmaul husna sebelum memulai pembelajaran, dan bagi peserta didik yang datang terlambat harus melakukan hal yang sama, tanpa melalui perintah guru mereka dapat langsung membaca asmaul. Hal tersebut juga dapat melatih kejujuran peserta didik, ketika mereka terlambat melakukan pembacaan asmaul husna mereka harus mengulangi kembali dari awal setelah semua peserta didik selesai. Karakter selanjutnya yang ditanamkan adalah hubungan baik antar peserta didik, di mana diwaktu istirahat misalnya, peserta didik selalu mendapat pengawasan dari para guru, sehingga bullying antar siswa dapat diminimalisir.

\section{Nilai-Nilai Karakter dalam Pesantren}

Pesantren yang diartikan sebagai tempat santri atau tempat murid mengaji dan sebagainya. Dalam komunitas pesantren terdapat santri, kiai, tradisi pengajian dan lainnya, dan terdapat pula bangunan yang dijadikan para santri untuk melaksanakan semua kegiatan selama 24 jam. Di dalam pesantren, khususnya pesantren tradisional sangat menjunjung tinggi nilai-nilai edukasi, seperti kesederhanaan, belajar tanpa pamrih, dan penuh tanggung jawab. Selain itu, sosok kiai di dalam pesantrenn merupakan figur sentral yang setiap harinya banyak mempengaruhi kepribadian santri. Sosok kiai sebagai guru pun biasanya tanpa pamrih mengharap bayaran dari kegiatan mengajarnya. Sedangkan dalam pesantren yang bercorak modern, nilai yang ditanamkan tidak sebatas pembentukan karakter santri, namun sudah melampaui dari itu. Pesantren pun selama ini dikenal sebagai lembaga pendidikan yang bersifat menyeluruh dan berkarakter. Artinya, seluruh potensi pikir dan dzikir, rasa dan karsa, jiwa dan raga dikembangkan melalui berbagai media pendidikan yang terbentuk dalam

${ }_{12}$ Zulfitria, Peranan Pembelajaran Tabfidz. Al quran dalam Pendidikan Karakter di Sekolah Dasar, Jurnal Kajian Penelitian Pendidikan dan Pembelajaran, Vol.1, No.2, (April 2017). 
suatu komunitas yang sengaja didesain secara integral untuk tujuan pendidikan komprehensif. ${ }^{13}$

Menurut K.H. Imam Zarkasyi, dalam buku Perkenalan Pondok Modern Gontor, pesantren didefinisikan sebagai lembaga pendidikan Islam dengan sistem asrama, di mana kiai sebagai sentral figurnya, masjid sebagai pusat kegiatan yang menjiwainya, dan pengajaran agama Islam di bawah bimbingan kiai yang diikuti santri sebagai kegiatan rutinnya. Sejak dulu pesantren dirasa sebagai lembaga edukasi yang cukup mengakar di masyarakat. Sosok kiai pesantren tradisional dipandang sebagai "figur ideal" yang dilegitimasi dan didukung penuh oleh masyarakat di sekitar pesantren. Sosok kiai yang menjadi "pemuas" kebutuhan rohani, santri, masyarakat dan memberikan alternatif pemechan terhadap problematika yang terdapat di umatnya. Karena itulah, pesantren merupakan "subkultur" yang akan melakukan pengikisan krisis dan pada gilirannya akan mampu menghimpun dan membentuk kultur tersendiri di lingkungannya. ${ }^{14}$

Tujuan pendidikan adalah pembentukan dan pembinaan akhlak mulia (karakter). Karakter merupakan hasil dari pendidikan, pelatihan, pembinaan, dan perjuangan keras serta sungguh-sungguh. Menurut Imam Al-Ghazali, sekiranya tabiat manusia tidak mungkin dapat dirubah, tentu nasihat dan bimbingan tidak ada gunanya. Menurutnya, sekiranya akhlah (karakter) itu tidak dapat menerima perubahan niscaya fatwa, nasihat, dan pendidikan adalah hampa. Untuk dapat mencapai tujuan pendidikan dalam pembinaan karakter maka diperlukan metode yang sesuai. Adapun metode-metode pembinaan karakter adalah:

1. Metode Keteladanan

Metode keteladanan yaitu suatu metode pendidikan dengan cara memberikan contoh yang baik kepada peserta didik, baik dalam ucapan maupun perbuatan. Keteladanan merupakan salah satu metode pendidikan yang diterapkan Rasulullah dan paling banyak pengaruhnya terhadap keberhasilan menyampaikan misi dakwahnya.

2. Metode Pembiasaan

Pembiasaan merupakan sebuah usaha untuk menanamkan kebiasaan. Sedangkan kebiasaan (habit) adalah cara bertindak yang persisten, uniform dan

${ }_{13}$ Ahmad Muhakamurrohman, Pesantren: Santri, Kiai, dan Tradisi, Jurnal Kebudayaan Islam IBDA', Vo.12, No.2, (Juli-Desember 2014).

${ }^{14}$ Ibid. 
hampir-hampir otomatis. Pembiasaan tersebut dapat dilakukan untuk membiasakan pada tingkah laku, keterampilan, kecakapan, dan pola pikir. Pembiasaan bertujuan untuk mempermudah melakukan. Karena seseorang yang telah mempunyai kebiasaan tertentu akan dapat melakukannya dengan mudah dan senang hati.

3. Metode Memberi Nasihat

Abdurrahman An Nahlawi mengatakan bahwa yang dimaksud dengan nasihat adalah penjelasan kebenaran dan kemaslahatan dengan tujuan menghindarkan orang yang dinasihati dari bahaya serta menunjukannya ke jalan yang mendatangkan kebaikan dan manfaat.

4. Metode Motivasi dan Intimidasi

Metode motivasi dan intimidasi dalam bahasa Arab disebut dengan uslub al-targhib wa al-tarbib, atau metode targhib dan tarbib. Targhib berasal dari kata raggaba yang berarti menyenangi, menyukai, dan mencintai. Kemudian kata itu diubah menjadi kata benda targhib yang mengandung makna suatu harapan untuk memperoleh kesenangan, kecintaan, dan kebahagiaan yang mendorong seseorang, sehingga timbul harapan dan semangat untuk memperolehnya.

5. Metode Persuasi

Metode persuasi adalah meyakinkan peserta didik tentang sesuatu ajaran dengan kekuatan akal. Penggunaan metode persuasi didasarkan atas pandangan bahwa manusia adalah makhluk yang berakal. Artinya, Islam memerintahkan kepada manusia untuk menggunakan akalnya dalam membedakan antara yang benar dan salah atau yang baik dan buruk.

6. Metode Kisah

Metode kisah merupakan salah satu upaya untuk mendidik murid agar dapat mengambil pelajaran dari kejadian di masa lampau. Apabila kejadian tersebut merupakan kejadian yang baik, maka harus diikutinya, sebaliknya jika kejadian tersebut merupakan kejadian yang bertentangan dengan agama Islam maka harus dihindari. Metode ini sangat baik dan digemari untuk anak-anak. Apabila metode ini disampaikan oleh orang yang pandai bercerita maka akan memberikan daya tarik tersendiri.

Proses pembinaan karakter di MI Nurul Ummah selama peserta didik di sekolah berlangsung hampir satu hari penuh. Bimbingan yang diberikan oleh madrasah kepada peserta didik seperti halnya bimbingan guru/kyai kepada santri 
selama di pesantren. Selama peserta didik di madrasah tidak hanya mendapat pengawasan dalam kaitannya dengan belajar-mengajar, akan tetapi penanaman niali-nilai karakter pesantren juga dilakukan. Karakter-karakter yang dimaksud meliputi; 1) pembiasaan berdoa, berdzikir dan bersholawat sebelum memulai aktivitas di madrasah; 2) hidup sederhana dan hemat dengan tidak diperbolehkannya peserta didik membawa uang saku selama di sekolah, sebagai gantinya mereka mendapat snack dan makan siang; 3) pembiasaan karakter hormat dan taat kepada orangtua atau guru; 4) pembiasaan melaksanakan ibadah wajib dan sunnah kepada peserta didik.

Penghormatan seorang murid kepada guru adalah ciri khas dari karakter yang ditanamkan kepada santri di pesantren. Kyai atau guru di pesantren merupakan sosok yang harus dihormati, hal itu menjadi referensi bagi proses penanaman karakter penghormatan peserta didik dengan orang tua atau guru di MI Nurul Ummah. Peserta didik diberi penjelasan tentang bagaimana cara menghormati guru atau orang tua, bahkan kepada guru atau kyai yang telah tiada mereka tetap dibiasakan untuk menghormati dengan cara menziarahi makam guru atau kyai di MI Nurul Ummah. Hal tersebut dilakukan agar peserta didik terbiasa menghormati orang tua yang berada di kehidupan mereka, tanpa memandang siapa sosok dari guru tertentu. Pembiasaan ziarah kubur dilakukan juga setelah sholat dhuha di setiap paginya, ziarah ke makam kyai dari pondok pesantren nurul ummah yang berada di dekat masjid merupakan pembiasaan karakter hormat kepada guru.

Selain itu, pembiasaan melaksanakan ibadah kepada peserta didik sejak dini, di mana peserta didik diwajibkan melakukan tiga kali sholat dalam sehari, yaitu sholat dhuha, dzuhur dan ashar secara berjamaah. Guru melakukan pendampingan ketika peserta didik melaksanakan sholat tersebut. Hal tersebut membuat respon positif dari masyarakat, khususnya orang tua murid yang mengakui terdapat perbaikan atau perubahan positif dari peserta didik, di mana setelah mereka bersekolah di MI Nurul Ummah kebiasaan sholat mereka semakin baik, khususnya dalam masalah bacaan sholat dan ketepatan waktu dalam melaksanakan sholat. Dalam melakukan bacaan sholat, khususnya sholat dhuha peserta didik dibiasakan melakukan dengan cara keras, hal itu merupakan proses pembelajaran terkait bacaan sholat yang benar, selain masalah gerakan juga diperhatikan.

Berdasarkan pernyataan orangtua peserta didik atas pendidikan dan pembinaan karakter anak mereka di MI Nurul Ummah dapat dikatakan bahwa 
program fullday school dengan penanaman karakter kepesantrenan mampu membekali anak untuk memiliki karakter yang baik. Salah satunya orangtua dari siswa bernama Tsaqib, dia mengatakan bahwa sejak Tsaqib sekolah di MI Nurul Ummah kelas satu telah mengalami beberapa perubahan dalam karakternya. Pada suatu hari ketika Tsaqib bangun tidur pukul enam pagi, dia menanyakan kepada ibunya kenapa ibunya tidak membangunkannya di waktu subuh sehingga dia harus mengganti sholat subuhnya. Ibunya memang biasanya membangunkan Tsabiq ketika subuh, dan tsaqib susah untuk bangun. Namun, dengan kejadian itu ibunya merasa terharu karena Tsaqib mengalami perubahan positif di usia yang masih dini. Selain itu, penghormatan Tsaqib terhadap orangtua juga meningkat, dia memulai mengatakan "maaf" ketika melakukan kesalahan kepada orangtuanaya, hal tersebut memang hal yang diajarkan kepada peserta didik di MI Nurul Ummah. Tsaqib juga melakukan hal yang sama kepada adiknya, pada suatu hari Tsaqib bermain dengan adiknya, dan tidak sengaja Tsaqib mengambil mainan adiknya sehingga adiknya menangis, Ibunya yang melihat itu hampir memarahi Tsaqib, akan tetapi tiba-tiba Tsaqib mengatakan "Maaf dek, ini mainannyya. Jangan nangis ya dek", melihat hal itu sang ibu pun terharu. Satu hal lagi yang berubah dari Tsaqib adalah dia tidak mau menonton tv lagi, yang sebelumnya dia selalu nonton tv sebelum tidur. Tsaqib memilih untuk membaca dan belajar sebelum tidur dibanding nonton tv. Pada suatu malam ketika ibunya menonton tv, Tsaqib mengatakan "Ibu tidak pernah mendengarkan aku, ibu suka nonton tv aja. Kata Pak guru kalau terlalu lama nonton tv nanti jadi bodoh". Mendengar pernyataan anaknya sang ibu merasa bersalah dan meminta maaf kepada anaknya. ${ }^{15}$

Pernyataan orangtua siswa tersebut memberi makna bahwa sekolah/madrasah merupakan rumah kedua bagi anak. Orangtua bertugas mendidik anak selama mereka di rumah, sedangkan guru merupakan orangtua kedua anak ketika di sekolah/madrasah. Berdasarkan hal ini, maka program fullday school memberikan pengaruh penting dalam pembinaan dan penanaman karakter peserta didik. Dengan fullday school, sekolah/madrasah dapat menjadi rumah kedua bagi peserta didik, dan guru yang selalu mendampingi mereka merupakan orangtua kedua. Program fullday school di MI Nurul Ummah dapat dijalankan dengan baik karena salah satunya nilai-nilai yang ditanamkan kepada peserta didik adalah nilai-nilai dalam pesantren. Untuk upaya kedepan dari MI Nurul Ummah adalah melakukan pengembangan dalam pembinaan karakter

${ }^{15} \mathrm{https} / / /$ bangkitmedia.com/belajar-di-minu-tsaqib-tidak-mau-lagi-nonton-tv/, diakses pada senin, 22 Oktober 2018, pukul 11 WIB. 
peserta didik melalui control dan pengamatan terhadap mereka ketika berada di rumah. Hal tersebut sebagai upaya menanamkan keistiqomahan dari karakter baik yang ditanamkan peserta didik selama di sekolah. Mereka diharapkan dapat memiliki karakter yang baik ketika berada di sekolah maupun di luar sekolah. Upaya tersebut merupakan bentuk sinergitas antara guru dan orangtua untuk kesuksesan pendidikan.

\section{Penutup}

Berdasarkan pembahasan di atas, maka dapat disimpulkan bahwa proses pembinaan karakter peserta didik harus dimulai sejak dini karena sesuai dengan tahap perkembangan mereka dalam menerima nilai atau moral. Pembinaan karakter harus dilakukan secara intensif, baik oleh orang tua maupun sekolah. Sehingga sekolah dengan model fullday school dianggap lebih efektif dalam membentuk karakter peserta didik. Selain itu, penanaman nilai-nilai kepesantrenan yang diberikan kepada peserta didik menjadi ciri khas tersendiri dalam praktik pendidikan karakter. Nilai-nilai dari pemahaman Al quran menjadi penting karena hal itu mdapat membekali karakter anak yang sesuai dengan ajaran $\mathrm{Al}$ quran. Selain itu, nilai-nilai luhur khas pesantren seperti penghormatan kepada guru/orang tua, hidup hemat atau sederhana, disiplin dan sebagainya dapat mendukung pembentukan pribadi anak yang berkarakter dan bernilai. Upaya pembinaan karakter dengan pengawasan ekstra guru di sekolah memberi dampak yang dapat dirasakan oleh guru maupun orangtua terhadap perubahan ke arah baik pada peserta didik. Akan tetapi, usaha tersebut tidak akan berjalan baik tanpa kerjasama antara orangtua dan guru. Selain itu, proses pengawasan dan perhatian guru sebaiknya terus ditingkatkan tidak hanya ketika peserta didik di sekolah saja, melainkan juga ketika peserta didik berada di rumah.

\section{Bibliography}

Ainissyifa, Hilda, Pendidikan Karakter dalam Perspektif Pendidikan Islam, Jurnal Pendidikan Universitas Garut, ISSN: 1907-932X, Vol.8, No.01, 2014;1-26.

Johansyah, Pendidikan Karakter dalam Islam; Kajian dari Aspek Metodologis, Jurnal Ilmiah Islam Futura, Vol.11, No.1, Agustus, 2011.

Koesoema. Doni.Pendidikan karakter, Jakarta: Grasindo, 2010. 
Lembaga Penelitian Universitas Negeri Yogyakarta, Tinjauan Berbagai Aspek Character Building: Bagaimana Mendidik Anak Berkarakter, Yogyakarta: Tiara Wacana, 2008.

Lickona, Thomas. Educating For Character: Bagaimana Sekolah Dapat Mengajarkan Sikap Hormat dan Tanggung Jawab, Jakarta: PT Bumi Aksara, 2012.

Muhakamurrohman, Ahmad, Pesantren: Santri, Kiai, dan Tradisi, Jurnal Kebudayaan Islam IBDA', Vo.12, No.2, (Juli-Desember 2014).

Nasution, S. Teknologi pendidikan, Jakarta: Bumi Aksara, 1994.

Nofiaturrahmah, Fifi.Metode Pendidikan Karakter di Pesantren, Jurnal Pendidikan Agama Islam, Vol.XI, No.2, Desember, 2014.

Setiyarini, Ida Nurhayati, dkk, Penerapan Sistem Pembelajaran "Fun and Fullday School" Untuk Meningkatkann Religiusitas Peserta Didik di SD IT Al Islam Kudus, Jurnal Teknologi Pendidikan dan Pembelajaran, Vol.2, No.2, hal. 231-244 (April 2014).

Suyanto, Slamet. Pendidikan Karakter untuk, Anak Usia Dini, Jurnal Pendidikan Anak, Vol.1, Edisi 1 Juni 2011.

Wiyani, Novan Ardi.Konsep Praktik, \& Strategi Membumikan Pendidikan Karakter di SD, Yogyakarta: Ar-Ruzz Media, 2013.

Zulfitria, Peranan Pembelajaran Tahfidz Al quran dalam Pendidikan Karakter di Sekolah Dasar, Jurnal Kajian Penelitian Pendidikan dan Pembelajaran, Vol.1, No.2, April 2017.

https://bangkitmedia.com/belajar-di-minu-tsaqib-tidak-mau-lagi-nonton-tv/, diakses pada senin, 22 Oktober 2018, pukul 11 WIB.

https://nasional.tempo.co/read/794640/3-alasan-menteri-muhadjir-full-dayschool-akan menyenangkan, diakses pada hari Jumat, 19 Oktober 2018 pukul 21.00. 